\title{
Plant and Soil
}

\section{Coping with drought: root trait variability within the perennial grass Dactylis glomerata captures a trade-off between dehydration avoidance and dehydration tolerance \\ --Manuscript Draft--}

Manuscript Number:

Full Title:

Article Type:

Keywords:

Corresponding Author:
PLSO-D-18-00529R1

Coping with drought: root trait variability within the perennial grass Dactylis glomerata captures a trade-off between dehydration avoidance and dehydration tolerance

Manuscript

cocksfoot; orchardgrass, drought; functional trade-off; intraspecific variability; root traits; plant strategies; water acquisition

Florence Volaire, $\mathrm{PhD}$

INRA Centre de Montpellier

Montpellier, FRANCE
Corresponding Author Secondary Information:

Corresponding Author's Institution:

\section{Corresponding Author's Secondary} Institution:

\section{First Author:}

First Author Secondary Information:

Order of Authors:

Florence Volaire, PhD

Pauline Bristiel, PhD

Catherine Roumet, $\mathrm{PhD}$

Cyrille Violle, PhD

\section{Order of Authors Secondary Information:}

Funding Information:
European Research Council (ERC-StG-2014-639706)
Dr Cyrille Violle

\section{Abstract:}

Response to Reviewers:

Background and Aims. Understanding plant adaptation to drought is a crucial challenge under climate change. This study aimed at investigating root traits and water use among plants exhibiting a range of dehydration avoidance and tolerance strategies to cope with drought.

Methods. Sixteen populations of the perennial grass Dactylis glomerata originating from Mediterranean to Scandinavian biogeographical regions were grown in long tubes to measure root depth potential under irrigation and root adaptation under severe drought. Water uptake under drought was used as proxy for dehydration avoidance. Root depth, biomass, and morphological traits of the deep roots were measured. We assessed plant survival after severe drought as a measure of dehydration tolerance.

Results. All populations had similar maximum rooting depth and specific root length. Compared to Northern and Temperate populations, Mediterranean populations had twice lower total and deep root biomass, thinner and denser deep roots. They were less affected by drought. This syndrome was associated with lower water uptake (lower dehydration avoidance) but higher survival to severe drought (dehydration tolerance).

Conclusion. The intraspecific variability in root traits captured a trade-off between dehydration avoidance and dehydration tolerance which illustrates contrasting adaptive plant and root strategies according to the biogeographical origins of populations.

Montpellier, October 2018

Dear lan Dodd, Plant and Soil Editor, 
1 Type of article: Full paper

2

Coping with drought: root trait variability within the perennial grass Dactylis glomerata captures a tradeoff between dehydration avoidance and dehydration tolerance Pauline BRISTIEL ${ }^{1}$, Catherine ROUMET ${ }^{2}$, Cyrille VIOLLE $^{2}$, Florence VOLAIRE $^{1 *}$

6

$7 \quad{ }^{1}$ CEFE, INRA, -, CNRS, Université de Montpellier, Université Paul Valéry Montpellier 3, EPHE, IRD,

8 Montpellier, France. pauline.bristiel@cefe.cnrs.fr; florence.volaire@cefe.cnrs.fr

$9{ }^{2}$ CEFE, CNRS, Université de Montpellier, Université Paul Valéry Montpellier 3, EPHE, IRD, Montpellier,

10 France. catherine.roumet@cefe.cnrs.fr; cyrille.violle@cefe.cnrs.fr

Short title: dehydration avoidance - dehydration tolerance trade-off 
Submitted:

Words counts:

21

- Main body of the text: 6296

22

- Summary: 197

23

- Introduction: 1160

24

- Materials and methods: 2099

25

- Results: 851

- Discussion: 1886

- Acknowledgements: 87

28

29 Number of figures: 7; 6 should be published in colour

30

Number of tables: 1

31 Supplementary material: 4 tables +1 Figure

32 


\section{SUMMARY}

Background and Aims. Understanding plant adaptation to drought is a crucial challenge under climate change. This study aimed to investigate root traits and water use of grass populations exhibiting a range of dehydration avoidance and tolerance strategies to cope with drought.

Methods. Sixteen populations of the perennial grass Dactylis glomerata originating from three biogeographical origins (Northern, Temperate and Mediterranean) were grown in long tubes. Plant biomass, rooting depth and morphological traits of deep roots were measured both under full irrigation and under severe drought. Water uptake under drought was used as a proxy for dehydration avoidance. Plant survival after severe drought was a measure of dehydration tolerance. Results. All populations had similar maximum rooting depth and specific root length. Compared to Northern and Temperate populations, Mediterranean populations had half total and deep root biomas but thinner and denser deep roots. They were less affected by drought. These traits were associated with less water uptake (lower dehydration avoidance) but greater survival to severe drought (enhanced dehydration tolerance). Conclusion. The intraspecific variability in root traits revealed a trade-off between dehydration avoidance and dehydration tolerance which illustrates contrasting adaptive plant and root strategies associated with the biogeographical origins of populations.

Key words: cocksfoot; orchardgrass, drought; functional trade-off; intraspecific variability; root traits; plant strategies; water acquisition. 
According to several climatic models, drought risk will dramatically increase during the century (Dai 2011; Sherwood and Fu 2014). Improving our understanding of the adaptive mechanisms underlying the response of wild and cultivated plant species to drought is a priority research avenue in both ecology and agronomy (e.g., Volaire et al., 2014; Kooyers, 2015).

To cope with drought, plants exhibit a range of physiological strategies that are defined as combinations of mechanistically linked responses and traits that lead to a particular type of behavior during a period of water deficit (Ludlow, 1989). Under moderate drought, a 'dehydration avoidance' strategy is expected, with plants characterized by roots able to reach moisture, and thereby to sustain growth (Brown et al. 2005). In this case, the main mechanism to maintain enough tissue water content for turgor is based on the optimization of water uptake, notably through a deep and efficient root system (Garwood and Sinclair 1979; Comas et al. 2013). Under more severe drought, a 'dehydration tolerance' strategy is linked to the maximization of the probability of survival rather than maintenance of growth rate (Levitt, 1972; Levitt et al., 1980). As such, plants display low tissue water content and preserve cells of surviving organs such as meristems from critical dehydration consequences by osmotic adjustment (West and Wullschleger 1990). In addition, under chronic severe summer droughts (e.g., around the Mediterranean Basin: Volaire et al. 2009), some perennial herbaceous plants exhibit a summer dormancy strategy that enhances their dehydration tolerance (Volaire and Norton, 2006; Gillespie and Volaire, 2017). However the role of root traits in regulating these strategies has been little examined (Zwicke et al., 2015). Measuring dehydration avoidance as the ability of plants to extract soil water during a drought and dehydration tolerance as the ability of plants to survive at a low soil water content (Volaire et al., 2014), the present study aims to investigate whether root traits and plant water use significantly differ among plants that exhibit a range of dehydration avoidance and tolerance.

The adaptive meaning of plant traits to drought can be usefully explored through the link between ecophysiological and ecological strategies (Volaire, 2018). As a general pattern, resource poor environments are likely to select for plants characterized by resource conservation strategies and 'slow traits', i.e. traits associated with slow growth rate, while resource rich environments select for opposite strategies, so-called resource acquisition strategies and 'fast' traits (Reich 2014). This framework identified root traits associated to water acquisition to tradeoff with root traits associated with water conservation (Prieto et al. 2015; Weemstra et al. 2016; Roumet et al. 2016; Fort et al. 2017). As a general rule, water acquisitive plants are expected to exhibit a deep root system with low carbon investment (i.e., high specific root length, low root tissue density, and small diameter; e.g., White and Snow, 2012; Freschet et al., 2017) allowing extensive soil exploration. At the other extreme, water conservative plants are expected to exhibit 'slower traits' such as thicker roots with high root tissue density, associated with longer root life span (McCormack et al. 2012). As underlined in former studies (Hernández et al. 2010; Lelièvre et al. 2011; Pérez-Ramos et al. 2013; Zwicke et al. 2015; Balachowski et al. 2016), it is then assumed that plants characterized by a dehydration avoidance strategy should have 'faster' root traits associated with efficient water acquisition. Conversely, it is hypothesized that plants characterized by a dehydration tolerance strategy should have 'slower' root traits associated with water conservation. 
To investigate the response of plants to drought, latitudinal gradients are considered as natural laboratories (De Frenne et al. 2013; Violle et al. 2014) since they allow comparing plants from contrasting environments. Perennial herbaceous species are an interesting model to explore drought response strategies since their perennial habit requires them to survive many successive years even under harsh conditions such as drought prone environments. In addition, as they dominate most grassland ecosystems, they have developed adaptive strategies to cope with different intensity and duration of droughts (Levitt 1980; Ludlow 1989; Turner 1997). The perennial grass species Dactylis glomerata has a very broad biogeographic distribution across most of Eurasia and northern Africa (Lumaret 1988; Borrill 1991). Previous work on this species showed a large intra-specific variability in above-ground traits and seasonal growth potential using a range of populations of D. glomerata originating from a large latitudinal gradient (Mediterranean to Scandinavia; Bristiel et al. 2018). Notably, the Mediterranean populations were summer dormant and survived severe drought with thinner and more lignified leaves, while Temperate and Northern populations were more summer active, drought sensitive with larger leaves. (Bristiel et al., 2018). However, the intra-specific variability in root systems has not been described in this species, although their large climate range likely relates to marked differences in root trait values and water use strategies.

In this study, sixteen populations of $D$. glomerata representative of three biogeographical origins (Northern, Temperate and Mediterranean) were grown in long tubes. Plant biomass and root traits were measured both under full irrigation and under severe experimental drought in order to investigate 1) the intraspecific variability in plant and root traits among populations from the three biogeographic origins, 2) the response of these traits to drought, 3) the relationships between traits and water use and finally 4) the relationship between dehydration avoidance and dehydration tolerance. We focus on rooting depth and on traits of deep roots (morphological traits, root mass and length densities), that have been little explored so far, since they are less accessible although they drive water uptake from the deepest soil layers where water remains available for a longer time during a severe drought (Maeght et al. 2013; Prieto et al. 2015; Fort et al. 2016, 2017). The water use during the drought period was used as a proxy of dehydration avoidance. Plants were grown in $2 \mathrm{~m}$ long tubes in order to determine rooting depth and deep root trait response to minimize rooting depth constraints. The biogeographic origin of populations should be associated with contrasting root traits when plants grow under non-limiting water supply while rooting depth and root biomass allocation are expected to increase under drought in order to enhance water uptake. In addition, we assumed that root traits should be associated to water use. According to the root economics framework (Roumet et al. 2016; Weemstra et al. 2016), 'slow' root traits such as a high root tissue density and a low specific root length should result in low water uptake and therefore water conservation. Conversely, 'fast' root traits, such as abundant and thin roots with high specific root length and low tissue density would enhance water acquisition and dehydration avoidance. These relationships between root traits and water use have rarely been explored using contrasting intra-specific populations. Ultimately, since populations originating from Mediterranean drought prone environment are more dehydration tolerant than Temperate and Northern populations less adapted to severe drought (Bristiel et al., 2018), a trade-off between dehydration avoidance and dehydration tolerance might exist in D. glomerata.

\section{MATERIAL AND METHODS}


The experiments were carried out at the CNRS (Centre National de la Recherche Scientifique) experimental field in Montpellier, southern France (433'N, $3^{\circ} 51^{\prime} \mathrm{E}, 100 \mathrm{~m}$ a.s.1.). The climate is Mediterranean subhumid (Daget, 1977), with cool to cold winters, frequent frosts in winter and severe water deficits in summer.

\section{Plant material}

Sixteen tetraploid populations of Dactylis glomerata L. (cocksfoot), were chosen from germplasm banks to be representative of three biogeographical origins (Northern, Temperate and Mediterranean) within a large latitudinal gradient (Norway to Morocco), with contrasting annual precipitation patterns ranging from 246 to $893 \mathrm{~mm}$ (Table S1). They were therefore expected to express various adaptive strategies, particularly regarding water use (Cooper 1964; Eagles 1967, 1971).

\section{Experimental design}

Two experiments were carried out in order to determine the dehydration avoidance and dehydration tolerance of the same D. glomerata populations.

\section{Dehydration avoidance experimentation: Long tube design}

Dehydration avoidance was assessed by determining the ability of the contrasting populations to take up water under non-limiting rooting depth conditions ( $2 \mathrm{~m}$ long tubes). Long transparent PVC tubes (6 cm diameter, $2 \mathrm{~m}$ long) were filled with $9 \mathrm{~kg}$ of substrate (75\% sand and $25 \%$ local soil). The local soil is a clay loam with $2.8 \%$ organic matter and $\mathrm{pH} 8.1$. Water content of the substrate at field capacity and wilting point were 24.1 and $2.9 \mathrm{~g}$ $\mathrm{H}_{2} 0$ per $100 \mathrm{~g}^{-1}$ dry soil respectively (measurements made on 3 replicates of substrate with standard saturation under vacuum, at INRA Orléans, France). PVC tubes were directly filled (without transparent plastic containing the soil) with three successive soil layers of decreasing density (density of $1.85,1.70$ and $1.6 \mathrm{~g} \mathrm{~cm}^{-3}$ respectively from the bottom third to the top third of the column) to simulate a natural gradient of soil density with denser soil at the bottom. They were covered with an opaque and insulating film to protect roots from solar radiation and inclined at $25^{\circ}$ to allow root development to be visible against the transparent tube wall (Fig 1). These $2 \mathrm{~m}$ long tubes allowed the comparison of the maximum rooting depth of all populations since only one reached $197 \mathrm{~cm}$ at the end of the experiment. The large tube volume $(5.6 \mathrm{~L})$ avoids a pot size effect on plant growth. Indeed according to Poorter et al (2012) an appropriate pot size is one in which the total plant biomass does not exceed $1 \mathrm{~g} \mathrm{~L}^{-1}$. In our study at the end of experiment, the ratio between the total plant biomass and the pot volume was much lower than this threshold: it ranged from $0.09 \mathrm{~g} \mathrm{~L}^{-1}$ (Mediterranean populations) to $2.5 \mathrm{~g} \mathrm{~L}^{-1}$ (Northern and Temperate populations). However, the small diameter of the tubes may have constrained root architecture especially the lateral and vertical root distribution and therefore may not reflect the distribution of roots in field soil (Hodgkinson et al. 2017), Despite these constraints, the tubes used remain appropriate for comparative studies.

Seeds from each D. glomerata population were sown in February 2013 and maintained fully irrigated and fertilized in pots. On the $10^{\text {th }}$ of February 2015 (day 0), one ramet of each population (with $5 \mathrm{~cm}$ root length and $5 \mathrm{~cm}$ shoot length) was transplanted into each tube with 6 replicates per population (total of 96 tubes). Tubes were placed outside and arranged as a randomized complete blocks, under a transparent roof to avoid natural precipitation and allow the experimental control of water supply (Fig. 1a). During the experiment, mean daily air temperature ranged from 14.5 to $28.5^{\circ} \mathrm{C}$ while maximum temperature reached $35.2^{\circ} \mathrm{C}$ in July. Plants were grown under optimal 
irrigation and fertilization for all populations during 5 months. On 5 June 2015 (day 114), when visible roots of all populations reached $140 \pm 18 \mathrm{~cm}$, the foliage of each plant was cut at $3 \mathrm{~cm}$ from soil level to determine the above-ground dry biomass (spring AGB, g DM plant ${ }^{-1}$, weighed after oven dried at $65^{\circ} \mathrm{C}$ for $48 \mathrm{~h}$ ) before the onset of the drought/irrigated summer treatments. The same day, all tubes were irrigated to field capacity $(24.1 \%$ gravimetric soil moisture). Then, the experimental treatments started: irrigation was stopped on half of the tubes to simulate an intensifying drought, the other half of the tubes were kept fully irrigated, as a control treatment.

\section{Plant sampling}

On the 20th of July 2015 (day 159 and 45 days after the onset of the drought/irrigated summer treatments), when full senescence of the foliage was reached for all populations, the whole soil column was carefully extracted from each tube and placed horizontally on wire netting. Shoots of each plant were cut at root insertion, oven-dried at $65^{\circ} \mathrm{C}$ for $48 \mathrm{~h}$, and weighed, to determine the summer above-ground biomass (summer AGB, g DM plant ${ }^{-1}$ ) produced by plants after the onset of the drought/irrigated summer treatments. In order to characterize root biomass distribution with depth, each soil column was divided into eight soil layers of $25 \mathrm{~cm}$ depth (Fig. 1b). Samples of soil (without roots) were immediately collected for each $25 \mathrm{~cm}$ soil layer depth and weighed. These soil samples were reweighed after oven-drying for $48 \mathrm{~h}$ at $105^{\circ} \mathrm{C}$ in order to obtain the soil water content of each soil layer. The remaining soil was gently brushed away from roots, taking care not to disturb root depth distribution, to measure the maximum rooting depth $(\mathrm{cm})$. Roots of each soil layer were then carefully washed free of soil in water (Fig. 1c). Roots from the soil layer above the deepest soil layer including roots, were frozen into plastic bags filled with water for further root morphological trait measurements (see Fig. 1, and the following section of material and methods). All other root samples were oven-dried at $65^{\circ} \mathrm{C}$ for $48 \mathrm{~h}$ and weighed.

At the whole plant level, the total root biomass was calculated as the sum of the root dry mass in each soil layer; the root: shoot ratio was the ratio between total root biomass and total AGB (sum of spring and summer AGB); the $95 \%$ rooting depth $(\mathrm{cm})$, i.e. the soil depth that contains $95 \%$ of the total root biomass, was calculated according to Schenk and Jackson (2002).

For the tubes that were not irrigated during 45 days, the total water used (Total WU; $\mathrm{g} \mathrm{H}_{2} \mathrm{O}_{\text {day }}^{-1}$ plant $^{-1}$ ) during this period was used as a proxy of the 'dehydration avoidance'. This was calculated as the difference between the initial soil water content in the tube at field capacity (soil volume exploited by roots x soil density x $24,1 \mathrm{~g} \mathrm{H}_{2} \mathrm{O}$ per $100 \mathrm{~g}^{-1}$ dry soil which is soil moisture at field capacity) and the remaining water in the soil explored by the roots for each tube (soil volume exploited by roots $\mathrm{x}$ soil density x soil moisture measured once at the final sampling on day 159). Similarly, the 'deep soil water use' (Deep soil WU; $\mathrm{g} \mathrm{H}_{2} \mathrm{O}$ day $^{-1}$ plant $^{-1}$ ) was calculated as the difference between the initial soil water reserve at field capacity in the deep soil layers $(100 \mathrm{~cm}$ - rooting depth) and the remaining water in this layer of soil explored by the roots measured on day 159. Due to the small column surface, and to the plant foliage covering most of the soil surface, even when plants were senescent at the end of the drought, we assumed that atmospheric demand was similar for each tube allowing the comparison of overall transpiration between populations.

Water use efficiency was not calculated since plants of the summer dormant Mediterranean populations have senescent foliage even under irrigation in summer. 
206 For each plant, root morphological traits were measured on deep roots from the last but one soil layer including roots (n-1; Fig. 1b). We thus focused on deep roots that are localized in the moistest soil layers and avoided the roots from the deepest soil layer (n) which were often not fully developed and composed of a single axis without branching. The frozen root samples were thawed and a representative sub-sample of roots (one representative 10 $\mathrm{cm}$ root axis) was scanned in water at $600 \mathrm{dpi}$ (Fig. 2). The resulting images were analyzed using WinRHIZO Pro software (ver. 2009, Regent Instrument Inc., Quebec, Canada) to determine mean root diameter (mm), length (m) and volume $\left(\mathrm{cm}^{3}\right)$. Root volume was calculated by Winrhizo as the product of root length times $\pi$ times the square of root diameter/2, assuming a cylindrical shape of roots. After scanning, the sub-samples and the remaining roots were oven-dried for $48 \mathrm{~h}$ at $65^{\circ} \mathrm{C}$ and weighed. On these deep roots scanned, a number of variables were calculated for each root sub-samples: root tissue density (RTD; ratio of subsample root dry mass to rootvolume, $\mathrm{g} \mathrm{cm}^{-3}$ ), specific root length (SRL; ratio of root length to root dry mass $\mathrm{g}^{-1}$ ) and mean root diameter (mm). Deep root biomass (corresponding to the $\mathrm{n}-1$ soil layer) was calculated as the sum of biomass of the scanned sub-sample and remaining roots $\left(\mathrm{g}\right.$ DM plant ${ }^{-1}$ ), and deep root length density $\left(\mathrm{RLD} ; \mathrm{m} \mathrm{cm}^{-3}\right)$ as (SRL $\mathrm{x}$ deep root dry mass)/soil layer volume.

Dehydration tolerance experimentation: Short pot design

To test for the existence of a trade-off between dehydration avoidance and dehydration tolerance, we used the data from a previous study which measured dehydration tolerance on the same $D$. glomerata populations grown in short pots by recording plant survival after a drought period (Bristiel et al., 2018). As roots were equally limited in depth for all the populations in short pots, plant drought survival mirrored plant dehydration tolerance under a similar soil water availability (Volaire 2008). It allowed us to discount the effect of rooting depth associated mainly with dehydration avoidance (Volaire \& Lelievre, 2001; Pérez-Ramos et al., 2013). This experiment is briefly described below.

In May, plants of each D. glomerata population were transplanted into $4 \mathrm{~L}, 23 \mathrm{~cm}$-high, $18 \mathrm{~cm}$-diameter pots (4 individuals per pot; 12 pots respectively per population) under an open-ended clear plastic tunnel and kept fully irrigated and fertilized. Pots were filled with a substrate composed of $65 \%$ local loamy-clay soil and $35 \%$ compost. In summer 2014, the soil moisture was raised to field capacity (60\% soil moisture) and irrigation was ceased thereafter. Pots were weighed every 2-5 days throughout the experiment to monitor the decrease in soil water content. Once full leaf senescence was reached in all populations, and when soil water content in the pots decreased to near $12 \%$ ( 27 to 35 days after irrigation cessation), plants were harvested at $3 \mathrm{~cm}$ height, then pots were rehydrated, thus ending the severe drought. All pots were re-watered at the same soil water content to ensure that plant survival corresponded to an identical final soil dehydration for all populations irrespective of their growth potential. The plants were kept rehydrated for 15 days after which dehydration survival was measured. Plants that had not produced new shoots after 15 days of rehydration were considered as dead. The survival rate was measured as the number of living plants divided by the total number of plants and is a proxy for dehydration tolerance.

\section{Data analysis}



mixed models were used to estimate the effect of origin of D. glomerata (i.e., Northern, Temperate or Mediterranean), treatment (irrigated versus drought), and their interaction, on total above-ground biomass, total root biomass, root: shoot ratio, summer above-ground biomass, maximum rooting depth, 95\% rooting depth, deep root biomass, mean root diameter, root tissue density, specific root length, and root length density. The aboveground biomass, root: shoot ratio, root tissue density, and root length density were log transformed, and total water use and deep soil water use underwent an arcsin transformation to fit model requirements. Population accounted for random effect. Linear models were followed by post-hoc tests using Tukey's correction for multiple comparisons ('lsmeans' package; Lenth, 2016). Dehydration survival differences among origins were tested using a non-parametric Kruskall-Wallis test followed by post-hoc comparisons ('kruskalmc' in 'pgirmess' package; Siegel and Castellan, 1988). Bivariate correlations among traits were calculated using Pearson's correlation tests.

A principal component analysis (PCA; 'ade4' package) was performed using eight variables measured on irrigated plants: total above-ground biomass and seven root traits (total root biomass, deep root biomass, maximum root depth, root tissue density, specific root length, root length density, root diameter). Total water use and deep soil water use that were measured under drought were used as supplementary variables in the PCA. The relationship between total water use in long tubes (used as a proxy of dehydration avoidance) and drought survival in short pots (dehydration tolerance) was explored to quantify a possible trade-off between the two strategies of dehydration avoidance and tolerance in these species.

\section{RESULTS}

\section{Intraspecific variability under summer irrigation}

Under full summer irrigation, the sixteen populations of $D$. glomerata exhibited a large range of above-ground and root trait values (Fig. 3; Table S2). The total above-ground biomass ranged from $0.69 \mathrm{~g}$ to $3.20 \mathrm{~g} \mathrm{DM} \mathrm{plant}^{-1}$ (Fig. 3A) while total root biomass ranged from 1.68 to $5.97 \mathrm{~g} \mathrm{DM}$ plant $^{-1}$ (Fig. 3B; Table S2). The maximum rooting depth ranged from 160 to $197 \mathrm{~cm}$ and the $95 \%$ rooting depth varied from 115 to $161 \mathrm{~cm}$ (Fig. 3E, F; Table S2). The root tissue density of deep roots, varied 3.5 fold among populations and their specific root length ranged from 115 to $429 \mathrm{~m} \mathrm{~g}^{-1}$ (Fig. 3I, J; Table S2).

As a general pattern, under full summer irrigation, Mediterranean populations differed from both Northern and Temperate populations (Fig. 3). Mediterranean populations produced significantly less above-ground biomass (total and in summer) and lower root biomass (approximatively 54\% less), resulting in a root: shoot ratio double that of the other populations (Fig. 3A, B, C, D). The very low summer above-ground biomass under irrigation of Mediterranean populations confirmed that these populations were summer dormant (Fig. 4D). Their root biomass and root length density in deep soil layers were also 2.4 and 2 times lower respectively (Fig. 3G, K). Deep roots of Mediterranean populations had a $16 \%$ lower mean diameter but double the tissue density (Fig. 3H, I) of both Northern and Temperate populations. However, the maximum rooting depth and specific root length were similar across all origins (Fig. 3E, J).

\section{Response to drought}


Moisture deficit affected above-ground and root traits differently according to the population of $D$. glomerata considered (Fig. S1, S2) and to their origin as illustrated by the significant origin $\mathrm{x}$ treatment interactions detected for 7 of the eleven traits studied (Table 1). The Northern and Temperate populations were more affected by drought than Mediterranean populations (Fig. 4). In comparison to irrigated plants, the overall growth of plants of Temperate and Northern populations was reduced under drought. They showed a greater root: shoot ratio (Fig 4C). Their above-ground biomass in summer was markedly reduced (26\% on average; Fig 4D) as a response of foliage senescence; they also showed lower $95 \%$ rooting depth (minus $16 \mathrm{~cm}$ on average; Fig. $4 \mathrm{~F}$ ) as compared to irrigated plants. Conversely, the root: shoot ratio, summer above-ground biomass and $95 \%$ rooting depth of Mediterranean populations were not affected by drought (Fig. 4C, D, F). Overall, the total and deep root biomass and the maximum rooting depth of the three population origin groups were not affected by drought (Fig. 4B, E). Deep root morphological traits (root tissue density, specific root length as well as the root length density) were unaffected by drought across all origins except the mean root diameter of Temperate populations which was $0.04 \mathrm{~mm}$ less under drought (Fig. 4 H).

Water use under drought

The total water use (Fig. 5A), used here as a proxy for dehydration avoidance, as well as the deep soil water use (Fig. 5B) were significantly lower in Mediterranean populations which took up $12 \%$ less water during the drought period than the Northern and Temperate populations.

The PCA performed on plant traits measured under irrigation and with total and deep soil water use under drought as supplementary variables (Fig. 6), captured $72.5 \%$ of the total variance in the first two axes (56.4\% on the first axis). The first PC axis opposed Mediterranean populations with high root: shoot ratio and root tissue density to both Northern and Temperate populations which had higher summer above-ground and root biomasses, higher root length density and larger root diameter, associated with higher water consumption under drought (high water use). The second PC axis (PC2: 16.1\%) which opposed the specific root length on one side and the maximum root depth on the other side, did not discriminate populations according to their origin. The total water use measured under drought was positively correlated with above-ground biomass, total and deep root biomass, mean deep root diameter, and root length density, and negatively correlated with the root: shoot ratio, maximum root depth and root tissue density, all measured under irrigation (Table S3). The relationships between the total water use and traits both measured under drought showed similar patterns but stronger relationships. Interestingly, the relationship between total water use measured under drought and maximum root depth was negative when maximum root depth was measured under irrigation but non-significant when measured under drought (Table S3). tolerance)

The dehydration tolerance measured by the plant survival after severe drought in short pots, was on average 3 fold higher for Mediterranean populations of D. glomerata than for both Northern and Temperate populations (Fig. S3; Bristiel et al. 2018). It was strongly negatively related $(r=-0.82, \mathrm{P}<0.001)$ to the dehydration avoidance estimated by the total water use measured under drought in long tubes (Fig. 7). Figure 7 also showed that Mediterranean populations of $D$. glomerata expressed a lower water use but a higher dehydration tolerance after severe drought as compared to Northern and Temperate populations. 
318 When grown in deep soil in tubes and under irrigation, the sixteen populations of D. glomerata showed considerable variation in root traits. We identified marked trait variation between origins, with Mediterranean populations showing highly contrasting traits as compared to both Northern and Temperate populations. Mediterranean populations of $D$. glomerata were characterized by a lower plant biomass, a higher root: shoot ratio, and thinner deep roots with a higher tissue density than Northern and Temperate populations. This suite of traits was associated with a lower water use and therefore a lower dehydration avoidance although Mediterranean populations exhibited a higher dehydration tolerance when they were subjected to severe drought in short pots.

\section{Variability in plant traits among populations from different biogeographic origins}

The reduced aerial growth and early leaf senescence induced by summer dormancy in Mediterranean populations even under irrigation, contribute to reduce plant evapotranspiration rate, and thereby soil water uptake (Volaire et al. 1998; Pérez-Ramos et al. 2013; Volaire 2018). Interestingly, Mediterranean populations of D. glomerata had a similar maximum rooting depth both in irrigated and drought conditions and their root mass and length densities in deep soil layers were much lower than those of Northern and Temperate populations. This genetic difference was unexpected since rooting depth comparisons between species across ecosystems showed that dry environments select for deeper root systems than wetlands (Canadell et al. 1996; Jackson et al. 1996; Schenk and Jackson 2002, 2005; Collins and Bras 2007). A deep root system is assumed to promote water uptake by allowing the roots to collect the resource where it still remains in the deepest soil layers, enhancing growth and drought resilience (Ho et al. 2005; Nardini et al. 2016; Yang et al. 2017). Further, even a small proportion of roots in deep and moist soil layers may be sufficient to sustain water absorption (Jackson et al. 1996; Nicotra et al. 2002). In another perennial grass (Phalaris aquatica), which exhibits summer dormancy like Mediterranean populations of D. glomerata used in this study, a deep root system was crucial for dehydration tolerance and plant survival since plants died when roots were severed (McWilliam and Kramer 1968). In Mediterranean populations of $D$. glomerata, increasing the root: shoot ratio and decreasing the shoot transpiration requirements rather than foraging deeper underground appears to be the preferred strategy. Moreover, the clearest difference in deep root morphology between Mediterranean populations and Northern and Temperate populations of D. glomerata was in their higher root tissue density. A high root tissue density has also been found in plants grown under stressful, resource poor environments (Craine et al. 2001; Kramer-Walter et al. 2016; Ostonen et al. 2017), at high latitude (Ostonen et al. 2017), and at high mean annual temperature (Freschet et al. 2017). Higher root tissue density might be due to narrower, more numerous xylem vessels (Wahl and Ryser 2000; Hummel et al. 2007) and higher lignification conferring a greater longevity (Ryser 1996) and drought resistance (Wahl and Ryser 2000; Fitter 2002), although it might negatively impact their hydraulic conductivity (Mapfumo et al. 1993). Deep roots of Mediterranean populations were also thinner than those of Northern and Temperate populations, although the opposite pattern has been observed both within three woody species located along a latitudinal gradient from temperate to subarctic boreal forest (latitudes $48^{\circ} \mathrm{N}$ and $69^{\circ} \mathrm{N}$ ) (Ostonen et al. 2017) and among 1115 species from contrasting growth forms and climatic areas (Freschet et al. 2017) in which mean root diameter, often measured on shallow roots, 
increased with increasing mean annual temperature. In our study, the thinner roots of the Mediterranean populations might allow extensive soil exploration for water per unit of biomass invested, with low biomass investment, efficient hydraulic conductance (Hernández et al. 2010; Comas et al. 2012) and a higher resistance to embolism of roots with smaller xylem vessel diameter (Fitter 1987; Alameda and Villar 2012). Although they were thinner and had a higher tissue density, deep roots of the Mediterranean populations of D. glomerata had similar specific root length (SRL) than those of Northern and Temperate populations. The unforeseen association of thin but dense roots in Mediterranean populations and thick roots with low tissue density in Northern and Temperate populations blurred variations in SRL in this study. As a consequence, variation of SRL among populations was independent from variation of root tissue density and mean root diameter, as already reported for seedlings of 66 tree species (Kramer-Walter et al., 2016). Conversely, the root system of Northern and Temperate populations was characterized by greater root biomass and deeper roots with lower tissue density. These trait values can be associated with wider vessels and higher hydraulic conductivity, but also to higher vulnerability to drought-induced embolism (Mcelrone et al. 2004; Wang et al. 2016). Although with a lower root: shoot ratio than Mediterranean populations, the greater deep root length density of Northern and Temperate populations reflected a 'water acquisitive' root trait strategy conferring greater ability to collect soil resources, notably water, as long as it remains accessible (Lobet et al. 2014).

\section{Response of plant traits to experimental drought}

Compared to Mediterranean populations, the Northern and Temperate populations were more affected by drought with a decrease of above-ground biomass, and an increase in root: shoot ratio. This is a well-known response to drought that allows plants to improve water foraging capacity ((Skinner and Comas 2010; Olmo et al. 2014; Markesteijn and Poorter 2009). Northern and Temperate populations also had more shallow roots (lower 95\% rooting depth) under drought than the control irrigated plants. The opposite pattern has been observed for different species, for which drought stress increased the proportion of deep roots compared to controls (Padilla and Pugnaire 2007; Skinner and Comas 2010; Olmo et al. 2014). Surprisingly, drought did not affect the values of any deep root morphological traits. Two reviews (Ostonen et al. 2007; Olmo et al. 2014) also reported no clear effect of drought on specific root length (SRL), but rather a great variability in the SRL response across species due to the contrasting response of the two components of SRL, i.e. the root tissue density (RTD) and the mean root diameter. In many studies, drought was associated with a greater RTD but a lower root diameter leading to a nil effect of drought on SRL. In our growth conditions, root morphological traits of the populations of D. glomerata are less plastic than in other species, maybe because we measured root traits in deep soil layers whereas they are more commonly measured in the driest shallow soil layers. In Mediterranean populations, the lack of response of above-ground and root traits to drought might be associated with summer dormancy and suggests that these populations are genetically adapted to severe drought, which contributes to prevent opportunistic plant re-growth after episodic summer rain, which may be fatal to the non-adapted plant under severe extended drought (Laude 1953; Norton et al. 2009).

\section{Relationships between water use under drought and plant traits}


The total water use under drought was closely related to plant traits measured both under irrigation and under drought. In both cases, water use was positively correlated with the summer above-ground biomass and thus the evaporative demand during the drought period. Greater water use was also positively related to the capacity of roots to acquire water especially in deep soil layers (deep soil water use). Both total and deep water use increased with greater root biomass and root length densities in deep soil layers and with thicker deep roots but not with deeper root systems. Conversely, lower water use was associated with high root: shoot ratios and high root tissue density, two traits related to resistance to drought and root longevity and thus to resource conservation in long lived tissues. These relationships confirm those obtained on twelve Mediterranean rangeland species grown in a common garden experiment (Fort et al. 2017). The first PC axis thus opposed traits related to water acquisition and those related to resource conservation. Contrary to the conceptual root economics framework (Roumet et al. 2016; Weemstra et al. 2016) suggesting that a high rate of soil resource acquisition is associated with high SRL (fine roots with low tissue density) this study showed that at the intraspecific level, plants with coarser roots can take up more water than plants with thinner roots. In addition, SRL and maximum rooting depth were unrelated to water use and independent from the water acquisition - conservation axis. This questions the role of SRL for water acquisition and suggests that root diameter and root tissue density are better predictors of plant water use than SRL or maximum root depth for D. glomerata at intraspecific level.

\section{A trade-off between dehydration avoidance and dehydration tolerance}

This study shows that the populations of $D$. glomerata that best tolerate dehydration, by surviving well at low soil water content under similar access to water in short pots, take up less water when this resource is accessible in long tubes. These results highlight that, at the intraspecific level, a strong trade-off exists between dehydration tolerance and dehydration avoidance strategies. The dehydration tolerance strategy can mainly be associated with some water conservative ('slow') root traits values while the dehydration avoidance can mainly be associated to water acquisitive ('fast') root traits values (Reich, 2014). Although counterintuitive, these results confirm our hypothesis that populations that invest least in water acquisition, survive water stress better when the soil water resource is limited. Former studies have also shown that plants exhibiting fast above-ground growth rate during a drought period also expressed low dehydration tolerance (Pearson et al., 2003; Volaire et al., 2014; Benavides et al., 2015; Bristiel et al. 2018). Above-ground, 'fast' traits (Reich 2014) are associated with poor survival of environmental stress. This study revealed the same pattern below ground, underlining that, in D. glomerata, root traits favoring access to water do not primarily contribute to dehydration tolerance. In their natural environments, Northern and Temperate populations of D. glomerata have developed a root strategy to uptake water, avoid dehydration and keep the plant growing under the moderate droughts they typically face. In contrast, within the same species, the Mediterranean populations have developed summer dormancy, dehydration tolerance and deep roots with high tissue density to maintain a minimum water uptake to sustain plant survival under chronic, intense and extended summer droughts.

Finally, this exploration of plant and root traits of a range of populations of D. glomerata grown in long tubes showed that all traits except specific root length and maximum rooting depth discriminated the populations according to their biogeographical origins. 
In the field, rooting depth was similar within a few summer dormant and summer active cultivars of D. glomerata (Lelièvre et al. 2011; Barkaoui et al. 2016). Summer dormant Mediterranean populations outperformed Temperate populations for survival to severe drought in deep soils and for all tested climate scenarios (Poirier et al. 2012). Our results showing that Northern and Temperate populations exhibit root traits associated with dehydration avoidance tend to confirm that this strategy is not adapted to limit plant mortality under severe drought in shallow soils. Conversely, dehydration tolerance associated with lower water use during a drought, can be the most efficient strategy to promote drought survival (Norton et al. 2014). This pattern should be tested further on more populations and species in order to select traits in the context of greater occurrence of intense drought under climate change.

\section{ACKNOWLEDGEMENTS}

437 Thanks to Pascal Chapon for excellent technical assistance, and to the 'Terrain d'experience' platform and the 438 Plateforme d'Analyses Chimiques en Ecologie both at CEFE-CNRS (Labex CEMEB). Thanks to Mark Norton 439 and anonymous reviewers for their relevant comments and text editing. Thanks to Hervé Gaillard (Unité 440 Sciences du Sol, INRA Orleans) for soil analysis. Pauline Bristiel was financially supported by INRA (EA 441 department). This study was supported by the European Research Council (ERC) Starting Grant Project 442 'Ecophysiological and biophysical constraints on domestication in crop plants' [Grant ERC-StG-2014-639706443 CONSTRAINTS]. 
Alameda D, Villar R (2012) Linking root traits to plant physiology and growth in Fraxinus angustifolia Vahl. seedlings under soil compaction conditions. Environ Exp Bot 79:49-57.

Balachowski JA, Bristiel PM, Volaire FA (2016) Summer dormancy, drought survival and functional resource acquisition strategies in California perennial grasses. Ann Bot 118:357-368. doi: 10.1093/aob/mcw109

Barkaoui K, Roumet C, Volaire F (2016) Mean root trait more than root trait diversity determines drought resilience in native and cultivated Mediterranean grass mixtures. Agric Ecosyst Environ. doi: 10.1016/j.agee.2016.06.035

Benavides R, Escudero A, Coll L, et al (2015) Survival vs. growth trade-off in early recruitment challenges global warming impacts on mountain trees. Perspect Plant Ecol Evol Syst 17:369-378. doi: 10.1016/j.ppees.2015.06.004

Bohnert HJ, Nelson DE, Jensen RJ (1995) Adaptations to Environmental Stresses. Plant Cell 7:1099-1111. doi: 10.1105/tpc.7.7.1099

Borrill M (1991) Evolution and genetic resources in cocksfoot. In: Tushiya \& Gupta (ed) Chromosome Engineering in Plants: Genetics, Breeding, Evolution, Part B. Elsevier Science Publishers, pp 379-398

Bristiel P., Gillespie L., Østrem L, Balachowski J., Violle C., Volaire F. (2018) Experimental evaluation of the robustness of the growth-stress tolerance trade-off within the perennial grass Dactylis glomerata. Functional Ecology 32: 1944-1958. DOI: 10.1111/1365-2435.13112

Brouwer R (1963) Some aspects of the equilibrium between overground and underground plant parts. Meded van het Inst voor Biol en Scheikd Onderz van Landbouwgewassen 213:31-39.

Brown H, Moot D, Pollock K (2005) Herbage production, persistence, nutritive characteristics and water use of perennial forages grown over 6 years on a Wakanui silt loam. New Zeal J Agric Res 48:423-439. doi: $10.1080 / 00288233.2005 .9513677$

Canadell J, Jackson RB, Ehleringer JB, et al (1996) Maximum rooting depth of vegetation types at the global scale. Oecologia 108:583-595. doi: 10.1007/BF00329030

Collins DBG, Bras RL (2007) Plant rooting strategies in water-limited ecosystems. Water Resour Res 43:1-10. doi: 10.1029/2006WR005541

Comas LH, Becker SR, Cruz VM V, et al (2013) Root traits contributing to plant productivity under drought. Front Plant Sci 4:442. doi: 10.3389/fpls.2013.00442

Comas LH, Mueller KE, Taylor LL, et al (2012) Evolutionary Patterns and Biogeochemical Significance of Angiosperm Root Traits. Int J Plant Sci 173:584-595. doi: 10.1086/665823

Cooper JP (1964) Climatic variation in forage grasses I. J Appl Ecol 1:45-61.

Craine JM, Froehle J, Tilman DG, et al (2001) The relationships among root and leaf traits of 76 grassland 
Daget P (1977) Le bioclimat méditerranéen: caractères généraux, modes de

caractérisation. Vegetatio 34: 1-20.

Dai A (2011) Drought under global warming: A review. Wiley Interdiscip Rev Clim Chang 2:45-65. doi: $10.1002 /$ wcc. 81

De Frenne P, Graae BJ, Rodriguez-Sanchez F, et al (2013) Latitudinal gradients as natural laboratories to infer species' responses to temperature. J Ecol 101:784-795. doi: 10.1111/1365-2745.12074

Eagles CF (1967) The effect of temperature on vegetative growth in climatic races of Dactylis glomerata in controlled environments. Ann Bot 31:31-39.

Eagles CF (1971) Effect of photoperiod on vegetative growth in two natural populations of Dactylis glomerata L. Ann Bot 35:75-86.

Fitter A (2002) Characteristics and Functions of Root Systems. In: Waisel Y, Eschel A, Kafkafi U (eds) Plant Roots, The hidden half, Third Edit. CRC Press, New York, pp 15-32

Fitter AH (1987) An Architectural Approach To The Comparitice Ecology Of Plant Root Systems. New Phytol 106:61-77. doi: 10.1111/j.1469-8137.1987.tb04683.x

Fort F, Cruz P, Lecloux E, et al (2016) Grassland root functional parameters vary according to a communitylevel resource acquisition-conservation trade-off. J Veg Sci 27:749-758. doi: 10.1111/jvs.12405

Fort F, Volaire F, Guilioni L, et al (2017) Root traits are related to plant water-use among rangeland Mediterranean species. Funct Ecol. doi: 10.1111/1365-2435.12888

Freschet GT, Valverde-Barrantes OJ, Tucker CM, et al (2017) Climate, soil and plant functional types as drivers of global fine-root trait variation. J Ecol 1-15. doi: 10.1111/1365-2745.12769

Garwood EA, Sinclair J (1979) Use of water by six grass species. 2. Root distribution and use of soil water. J Agric Sci 93:25. doi: 10.1017/S0021859600086081

Gillepsie L, Volaire F (2017) Are winter and summer dormancy symmetrical seasonal adaptive strategies? The case of temperate herbaceous perennials. Ann. Bot. 119: 311-323, doi:10.1093/aob/mcw264

Hernández EI, Vilagrosa A, Pausas JG, Bellot J (2010) Morphological traits and water use strategies in seedlings of Mediterranean coexisting species. Plant Ecol 207:233-244. doi: 10.1007/s11258-009-9668-2

Hodgkinson L, Dodd IC, Binley A, Ashton RW, White RP, Watts CW, Whalley WR. (2017). Root growth in field-grown winter wheat: Some effects of soil conditions, season and genotype. European Journal of Agronomy, 91: 74-83. 
Ho MD, Rosas JC, Brown KM, Lynch JP (2005) Root architectural tradeoffs for water and phosphorus acquisition. Funct Plant Biol 32:737. doi: 10.1071/FP05043

Hummel I, Vile D, Violle C, Devaux J, Ricci B., Blanchard A, Garnier E, Roumet C (2007). Relating root structure and anatomy to whle plant functioning in 14 herbaceous Mediterranean species. New Phytologist, 173: $313-321$.

Jackson RB, Canadell J, Ehleringer JR, et al (1996) International Association for Ecology A Global Analysis of Root Distributions for Terrestrial Biomes A global analysis of root distributions for terrestrial biomes. Source: Oecologia 108:389-411. doi: 10.1007/BF00333714

Kooyers NJ (2015) The evolution of drought escape and avoidance in natural herbaceous populations. Plant Sci 234:155-62. doi: 10.1016/j.plantsci.2015.02.012

Kramer-Walter KR, Bellingham PJ, Millar TR, et al (2016) Root traits are multidimensional: specific root length is independent from root tissue density and the plant economic spectrum. J Ecol 104:1299-1310. doi: $10.1111 / 1365-2745.12562$

Laude HM (1953) The Nature of Summer Dormancy in Perennial Grasses. Bot Gaz 114:284-292. doi:

$$
10.1086 / 335770
$$

Lelièvre F, Seddaiu G, Ledda L, et al (2011) Water use efficiency and drought survival in Mediterranean perennial forage grasses. F Crop Res 121:333-342. doi: 10.1016/j.fcr.2010.12.023

Lenth R V. (2016) Least-Squares Means: The $R$ Package Ismeans. J Stat Softw. doi: 10.18637/jss.v069.i01

Levitt J (Jacob) (1980) Responses of plants to environmental stresses. Academic Press

Li H, Liu B, McCormack ML, Ma Z, Guo D. (2017), Diverse belowground resource strategies underlie plant species coexistence and spatial distribution in three grasslands along a precipitation gradient. New Phytol, 216: $1140-1150$.

Lobet G, Couvreur V, Meunier F, et al (2014) Plant Water Uptake in Drying Soils. Plant Physiol 164:16191627. doi: 10.1104/pp.113.233486

Ludlow MM (1989) Strategies of response to water stress. Struct. Funct. Responses to Environ. Stress $269-81$.

Lumaret R (1988) Cytology, genetics, and evolution in the genus Dactylis. CRC Crit Rev Plant Sci 7:55-91.

Maeght J-L, Rewald B, Pierret A (2013) How to study deep roots-and why it matters. Front Plant Sci 4:299. doi: 10.3389/fpls.2013.00299

Malik RS, Dhankar JS, Turner NC (1979) Influence of soil water defecits on root growth of cotton seedlings. Plant Soil 115:109-115.

Mapfumo E, Aspinwall D, Hancock T, Sedgley M (1993) Xylem development in relation to water uptake by 
Markesteijn L, Poorter L (2009) Seedling root morphology and biomass allocation of 62 tropical tree species in relation to drought- and shade-tolerance. J Ecol 97:311-325. doi: 10.1111/j.1365-2745.2008.01466.x

McCormack LM, Adams TS, Smithwick EAH, Eissenstat DM (2012) Predicting fine root lifespan from plant functional traits in temperate trees. New Phytol 195:823-831. doi: 10.1111/j.1469-8137.2012.04198.x

Mcelrone AJ, Pockman WT, Martínez-vilalta J, et al (2004) Variation in xylem structure and function in stems and roots. New Phytol 163:507-517.

McWilliam J, Kramer P (1968) The nature of the perennial response in Mediterranean grasses. I. Water relations and summer survival in Phalaris. Aust J Agric Res 19:381. doi: 10.1071/AR9680381

Nardini A, Casolo V, Dal Borgo A, et al (2016) Rooting depth, water relations and non-structural carbohydrate dynamics in three woody angiosperms differentially affected by an extreme summer drought. Plant, Cell Environ 39:618-627. doi: 10.1111/pce.12646

Nicotra A, Babicka N, Westoby M (2002) Seedling root anatomy and morphology: an examination of ecological differentiation with rainfall using phylogenetically independent contrasts. Oecologia 130:136-145. doi: $10.1007 / \mathrm{s} 004420100788$

Norton MRA, Lelièvre FB, Volaire FB (2014) Measuring dehydration tolerance in pasture grasses to improve drought survival. Crop Pasture Sci 65:828-840.

Norton MR, Volaire F, Lelièvre F, Fukai S (2009) Identification and measurement of summer dormancy in temperate perennial grasses. Crop Sci 49:2347-2352. doi: 10.2135/cropsci2009.06.0319

Olmo M, Lopez-Iglesias B, Villar R (2014) Drought changes the structure and elemental composition of very fine roots in seedlings of ten woody tree species. Implications for a drier climate. Plant Soil 384:113-129. doi: $10.1007 / \mathrm{s} 11104-014-2178-6$

Ostonen I, Lohmus K, Helmisaari H-S, et al (2007) Fine root morphological adaptations in Scots pine, Norway spruce and silver birch along a latitudinal gradient in boreal forests. Tree Physiol 27:1627-1634. doi: 10.1093/treephys/27.11.1627

Ostonen I, Truu M, Helmisaari H-S, et al (2017) Adaptive root foraging strategies along a boreal-temperate forest gradient. New Phytol 215:977-991. doi: 10.1111/nph.14643

Padilla FM, Pugnaire FI (2007) Rooting depth and soil moisture control Mediterranean woody seedling survival during drought. Funct Ecol 21:489-495. doi: 10.1111/j.1365-2435.2007.01267.x

Pearson TRH, Burslem DFRP, Goeriz RE, Dalling JW (2003) Regeneration niche partitioning in neotropical pioneers: Effects of gap size, seasonal drought and herbivory on growth and survival. Oecologia 137:456465. doi: 10.1007/s00442-003-1361-x 
Pérez-Ramos IM, Volaire F, Fattet M, et al (2013) Tradeoffs between functional strategies for resource-use and drought-survival in Mediterranean rangeland species. Environ Exp Bot 87:126-136. doi: 10.1016/j.envexpbot.2012.09.004

Poirier M, Durand J-LL, Volaire F (2012) Persistence and production of perennial grasses under water deficits and extreme temperatures: Importance of intraspecific vs. interspecific variability. Glob Chang Biol 18:3632-3646. doi: 10.1111/j.1365-2486.2012.02800.x

Poorter H, Fiorani F, Stitt M, Schurr U, Finck A, Gibon Y, Usadel B, Munns R, Atkin OK, Tardieu F, Pons TL. (2012) The art of growing plants for experimental purposes: a practical guide for the plant biologist Review. Functional Plant Biology, 39: 821-838.

Prieto I, Roumet C, Cardinael R, et al (2015) Root functional parameters along a land-use gradient: Evidence of a community-level economics spectrum. J Ecol 103:361-373. doi: 10.1111/1365-2745.12351

Reich PB (2014) The world-wide "fast-slow" plant economics spectrum: A traits manifesto. J Ecol 102:275-301. doi: $10.1111 / 1365-2745.12211$

Roumet C, Birouste M, Picon-Cochard C, et al (2016) Root structure-function relationships in 74 species: evidence of a root economics spectrum related to carbon economy. New Phytol 210:815-826. doi: $10.1111 /$ nph. 13828

Ryser P (1996) The Importance of Tissue Density for Growth and Life Span of Leaves and Roots: A Comparison of Five Ecologically Contrasting Grasses. Funct Ecol 10:717. doi: 10.2307/2390506

Schenk HJ, Jackson RB (2002) The global biogeography of roots. Ecol Monogr 72:311-328. doi: 10.1890/00129615(2002)072[0311:TGBOR]2.0.CO;2

Schenk HJ, Jackson RB (2005) Mapping the global distribution of deep roots in relation to climate and soil characteristics. Geoderma 126:129-140. doi: 10.1016/j.geoderma.2004.11.018

Sherwood S, Fu Q (2014) A drier future ? Science (80- ) 343:737-739.

Siegel S, Castellan NJ (1988) Nonparametric statistics for the behavioral sciences. McGraw-Hill

Skinner RH, Comas LH (2010) Root distribution of temperate forage species subjected to water and nitrogen stress. Crop Sci 50:2178-2185. doi: 10.2135/cropsci2009.08.0461

Tjoelker MG, Craine JM, Wedin D, et al (2005) Linking leaf and root trait syndromes among 39 grassland and savannah species. New Phytol 167:493-508. doi: 10.1111/j.1469-8137.2005.01428.x

Turner NC (1997) Further Progress in Crop Water Relations. Adv Agron 58:293-338. doi: 10.1016/S00652113(08)60258-8

Violle C, Reich PB, Pacala SW, et al (2014) The emergence and promise of functional biogeography. Proc Natl Acad Sci 111:13690-13696. doi: 10.1073/pnas.1415442111 
Volaire F (2008) Plant traits and functional types to characterise drought survival of pluri-specific perennial herbaceous swards in Mediterranean areas. Eur J Agron 29:116-124. doi: 10.1016/j.eja.2008.04.008

Volaire F. (2018) A unified framework for plant adaptive strategies to drought: across scales and disciplines. Global Change Biology, 00:1-10.https://doi.org/10.1111/gcb.14062

Volaire F., Norton M. (2006) Summer dormancy in perennial temperate grasses. Ann Bot 98, 5: 927-933.

Volaire F, Barkaoui K, Norton M (2014) Designing resilient and sustainable grasslands for a drier future: Adaptive strategies, functional traits and biotic interactions. Eur J Agron 52:81-89. doi: 10.1016/j.eja.2013.10.002

Volaire F, Norton MR, Lelièvre F (2009) Summer Drought Survival Strategies and Sustainability of Perennial Temperate Forage Grasses in Mediterranean Areas. Crop Sci 49:2386. doi: 10.2135/cropsci2009.06.0317

Volaire F, Thomas H, Lelièvre F (1998) Survival and recovery of perennial forage grasses under prolonged Mediterranean drought: I. Growth, death, water relations and solute content in herbage and stubble. New Phytol 140:439-449. doi: 10.1046/j.1469-8137.1998.00288.x

Wahl S, Ryser P (2000) Root tissue structure is linked to ecological strategies of grasses. New Phytol 148:459471.

Wang Y, Dong X, Wang H, et al (2016) Root tip morphology, anatomy, chemistry and potential hydraulic conductivity vary with soil depth in three temperate hardwood species. Tree Physiol 36:99-108. doi: 10.1093/treephys/tpv094

Weemstra M, Mommer L, Visser EJW, et al (2016) Towards a multidimensional root trait framework: a tree root review. New Phytol. doi: 10.1111/nph.14003

West CP, Wullschleger SD (1990) Osmotic adjustement in tissues of tall fescue in response to water deficit. Environ Exp Bot 30:149-156.

White TA, Snow VO (2012) A modelling analysis to identify plant traits for enhanced water-use efficiency of pasture. Crop Pasture Sci 63:63-76. doi: 10.1071/CP11250

Yang F, Feng Z, Wang H, et al (2017) Deep soil water extraction helps to drought avoidance but shallow soil water uptake during dry season controls the inter-annual variation in tree growth in four subtropical plantations. Agric For Meteorol 234-235:106-114. doi: 10.1016/j.agrformet.2016.12.020

Zwicke M, Picon-Cochard C, Morvan-Bertrand A, et al (2015) What functional strategies drive drought survival and recovery of perennial species from upland grassland? Ann Bot 116:1001-1015. doi: 10.1093/aob/mcv037 
640 Table 1. Results of linear mixed models testing the effect of origin, treatment (irrigated or drought) and their

641 interaction on above ground and root variables of 16 populations of Dactylis glomerata from three climatic origins. The effect of origin on dehydration survival was tested using a Kruskal Wallis test.

\begin{tabular}{|c|c|c|c|c|c|c|c|c|c|c|c|c|}
\hline \multirow[b]{2}{*}{ Model variables } & \multirow[b]{2}{*}{ Unit } & \multirow[b]{2}{*}{$n$} & \multicolumn{3}{|c|}{ Origin } & \multicolumn{3}{|c|}{ Treatment } & & \multicolumn{3}{|c|}{ Interaction } \\
\hline & & & d.f. & $F$ & $P$ & d.f. & $F$ & $P$ & & d.f. & $F$ & $P$ \\
\hline Total above ground biomass (log) & g DM plant $^{-1}$ & 95 & 2 & 149,1 & $<0.001$ & 1 & 19,2 & $<0.001$ & & 2 & 5,1 & 0,008 \\
\hline Total root biomass & g DM plant $^{-1}$ & 95 & 2 & 31,2 & $<0.001$ & 1 & 0,1 & 0,80 & & 2 & 3,8 & 0,02 \\
\hline Root : shoot (log) & - & 95 & 2 & 45,3 & $<0.001$ & 1 & 30,2 & $<0.001$ & & 2 & 0,2 & 0,76 \\
\hline \multicolumn{2}{|c|}{ Summer above ground biomass (logg DM plant ${ }^{-1}$} & 95 & 2 & 59,4 & $<0.001$ & 1 & 15,2 & $<0.001$ & & 2 & 6,0 & 0,003 \\
\hline Maximum root depth & $\mathrm{cm}$ & 95 & 2 & 2,4 & 0,09 & 1 & 6,1 & 0,01 & & 2 & 1,7 & 0,19 \\
\hline $95 \%$ rooting depth & $\mathrm{cm}$ & 95 & 2 & 5,0 & 0,008 & 1 & 9,4 & 0,002 & & 2 & 7,7 & $<0.001$ \\
\hline Deep root biomass & g DM plant $^{-1}$ & 95 & 2 & 22,6 & $<0.001$ & 1 & 0,4 & 0,55 & & 2 & 1,6 & 0,21 \\
\hline Mean root diameter & $\mathrm{mm}$ & 95 & 2 & 12,3 & $<0.001$ & 1 & 1,4 & 0,24 & & 2 & 9,5 & $<0.001$ \\
\hline Root tissue density (log) & $\mathrm{g} \mathrm{cm}^{-3}$ & 95 & 2 & 15,5 & $<0.001$ & 1 & 4,3 & 0,04 & & 2 & 4,3 & 0,01 \\
\hline Specific root length & $\mathrm{mg}^{-1}$ & 95 & 2 & 0,9 & 0,41 & 1 & 6,9 & 0,01 & & 2 & 1,5 & 0,22 \\
\hline Root length density (log) & $\mathrm{m} \mathrm{cm}^{-3}$ & 95 & 2 & 43,9 & $<0.001$ & 1 & 1,5 & 0,22 & & 2 & 5,3 & 0,01 \\
\hline Total water use & g plant ${ }^{-1}$ day $^{-1}$ & 47 & 2 & 27,6 & $<0.001$ & - & - & - & - & - & - & - \\
\hline \multirow[t]{2}{*}{ Deep soil water use } & g plant ${ }^{-1}$ day $^{-1}$ & 47 & 2 & 42,8 & $<0.001$ & - & - & - & - & - & - & - \\
\hline & & $n$ & d.f. & $\chi^{2}$ & $P$ & & & & & & & \\
\hline Dehydration tolerance & $\%$ & 16 & 2 & 6,8 & 0,03 & & & & & & & \\
\hline
\end{tabular}


Figure 1. a) Experimental design of the long tube experiment comparing above and below ground traits of sixteen populations of Dactylis glomerata grown under drought and irrigation; b) diagram illustrating the plant harvest protocol and the variables measured or calculated; soil depth $(\mathrm{cm})$ is indicated on the left side of the soil column which was divided into eight sections represented by dotted lines. Variables in italics were measured on roots harvested in the last but one soil layer (n-1) including roots. Total and deep soil water use were measured for plants grown under drought; c) picture of roots harvested in a $25 \mathrm{~cm}$ soil layer; d) picture of a $10 \mathrm{~cm}$ root axis used for morphological trait measurement.

Figure 2. Illustration of root axes differences between the three origins of Dactylis glometata and between treatments (IR: irrigated; DR: drought). Images were obtained from the root scans at 600 dpi used to perform root morphological trait analysis. For comparative purposes, roots of the same populations (for each origin) are presented. Each picture represents one $10 \mathrm{~cm}$ long-root axis.

Figure 3. Boxplots of above ground and root traits measured under irrigation on 16 populations of D. glomerata. Total above ground biomass (Total AGB), total root biomass (Total RB), summer above ground biomass (Sum. AGB), deep root biomass (Deep RB), root tissue density (RTD), specific root length (SRL), root length density (RLD). Each point represents a mean value by population according to their origin: Northern in blue, Temperate in green and Mediterranean in red. Small letters indicate significant differences among origins (Tukey's post hoc test, $\mathrm{P}<0.05$ ).

Figure 4. Mean values and standard error of eleven traits measured on 16 populations of D. glomerata from three bioclimatic regions: Northern in blue, Temperate in green and Mediterranean in red. Traits were measured under irrigated $(\square)$ and drought $(\Delta)$ conditions. Total above ground biomass (Total AGB), total root biomass (Total RB), summer above ground biomass (Sum. AGB), deep root biomass (Deep RB), root tissue density (RTD), specific root length (SRL), root length density (RLD). Small letters indicate significant differences between both origins and treatments (i.e., irrigated or drought; Tukey post hoc test; $P<0.05)$

Figure 5. Mean values with standard errors of (A) total water use and, (B) deep soil water use measured at the end of the drought period on 16 populations of D. glomerata from different origins, Northern in blue, Temperate in green and Mediterranean in red. Small letters indicate significant differences between origins (Tukey test; $P<0.05$ ).

Figure 6. Principal component analysis performed on ten above ground and root traits of 16 populations of $D$. glomerata, measured under irrigation. Total root biomass (Total RB ), deep root biomass (Deep RB), maximum root depth, 95\% rooting depth, root tissue density (RTD), specific root length (SRL), mean root diameter, summer above ground vegetative biomass (summer AGB), root length density (RLD), and root: shoot ratio (Root: Shoot), contributed to the analysis (solid arrows on the correlation circle (A)). Total water use (total WU), and deep soil water use (deep soil WU), were measured at the end of the drought 
period as a proxy of dehydration avoidance, and were used as supplementary variables (orange arrows). In figure $6(\mathrm{~B})$, populations (points) were grouped by origin (NOR: northern in blue, TEMP: temperate in green, MED: Mediterranean in red) according to their barycenter.

Figure 7. Relationship between dehydration tolerance (\%) and dehydration avoidance. Triangles represent population mean values displayed by origin: Northern in blue, Temperate in green and Mediterranean in red. Regression lines show linear relationship, $R^{2}$ with associated P-value (***<0.001) is represented.

Table S1. List of the 16 populations of Dactylis glomerata. Climatic data associated with their origins were collected from the WorldClim data set (http://www.worldclim.org; Hijmans et al., 2005). Seeds from Northern populations were provided by the Nordic Genetic Resource Center (NordGen). Temperate ecotypes and cultivars, and population 'Porto', were provided by the plant genetic resources information system of the National Institute for Agronomical Research (INRA, France, Lusignan). The Sicilian ecotype came from University of Catania, Italy. The Moroccan ecotypes came from INRA Rabat, Morocco.

Table S2. Mean and range of the traits measured under irrigation or under drought on 16 populations of $D$. glomerata.

Table S3. Root biomass distribution in soil columns $(0-200 \mathrm{~cm})$ : Mean and standard deviation of root biomass for each $25 \mathrm{~cm}$ layer for Northern, Temperate and Mediterranean populations of D. glomerata under drought or irrigation.

Table S4. Correlations between the total water use measured under drought and eleven traits measured under irrigation or under drought. The $R$ coefficient of Pearson correlations were represented with associated Pvalue (*, $\mathrm{P}<0.05 ; * *, \mathrm{P}<0.01 ; * * *, \mathrm{P}<0.001$; ns: not significant).

Figure S5. Mean values and standard errors of dehydration tolerance (plant survival rate in short pots after severe drought) measured on 16 populations of D. glomerata from different origins: Northern in blue, Temperate in green and Mediterranean in red. Letters indicate significant differences between origins (Kruskal-Wallis test; $P<0.05$ ). 
a)

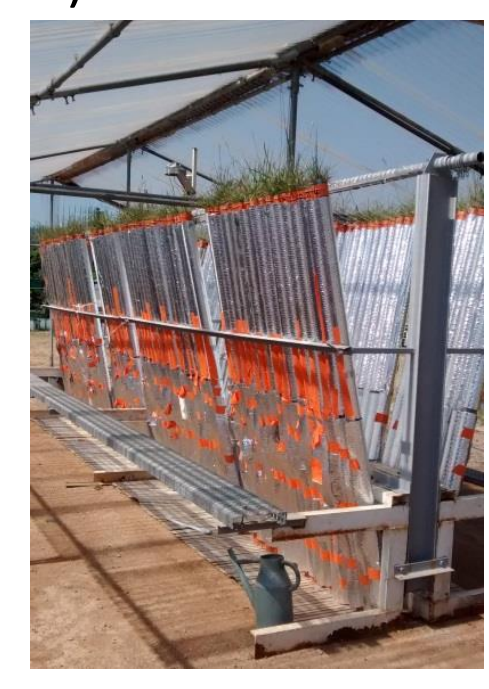

d)

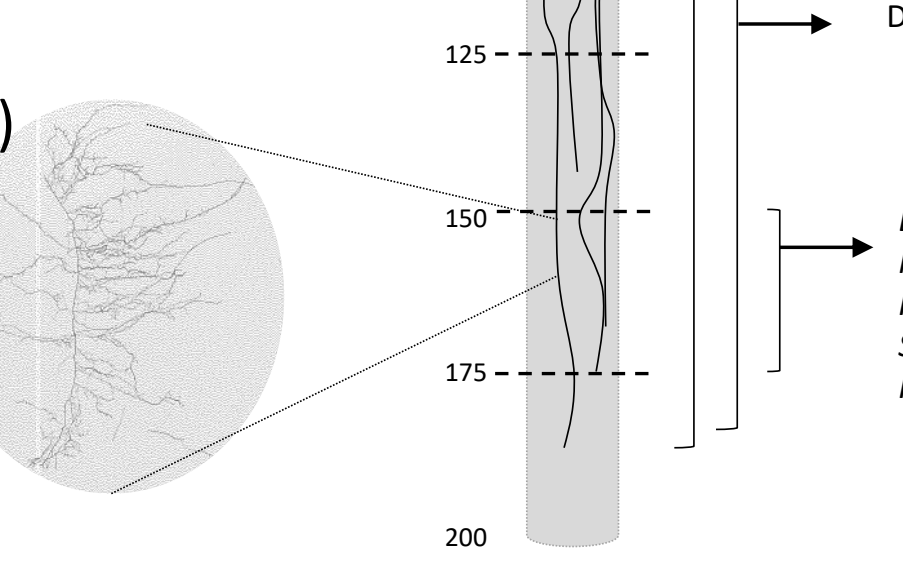

200 b) $\longrightarrow$ Above-ground biomass (g DM plant ${ }^{-1}$ )

Total root biomass (g DM plant ${ }^{-1}$

Maximum root depth $(\mathrm{cm})$

$95 \%$ rooting depth $(\mathrm{cm})$

Total soil water use $\left(\mathrm{g} \mathrm{H}_{2} \mathrm{O}\right.$ plant $^{-1}$ day $\left.^{-1}\right)$

c)

$25 \mathrm{~cm}$ root section

Deep root biomass (g DM plant ${ }^{-1}$ )

Mean root diameter $(\mathrm{mm})$

Root tissue density (RTD; $\mathrm{g} \mathrm{cm}^{-3}$ )

Specific root length $\left(S R L ; \mathrm{m} \mathrm{g}^{-1}\right)$

Root length density ( $\left.R L D ; \mathrm{Cm} \mathrm{cm}^{-3}\right)$ 


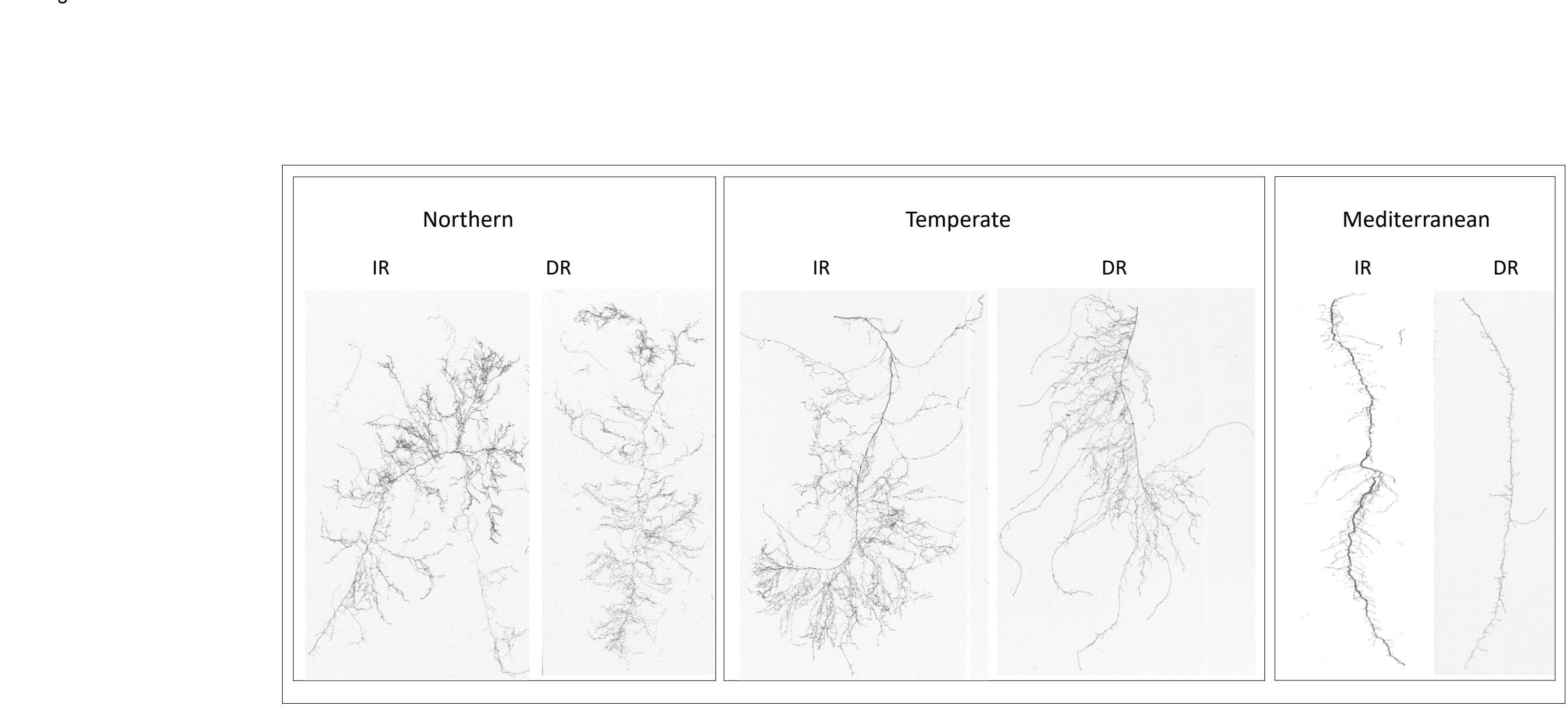



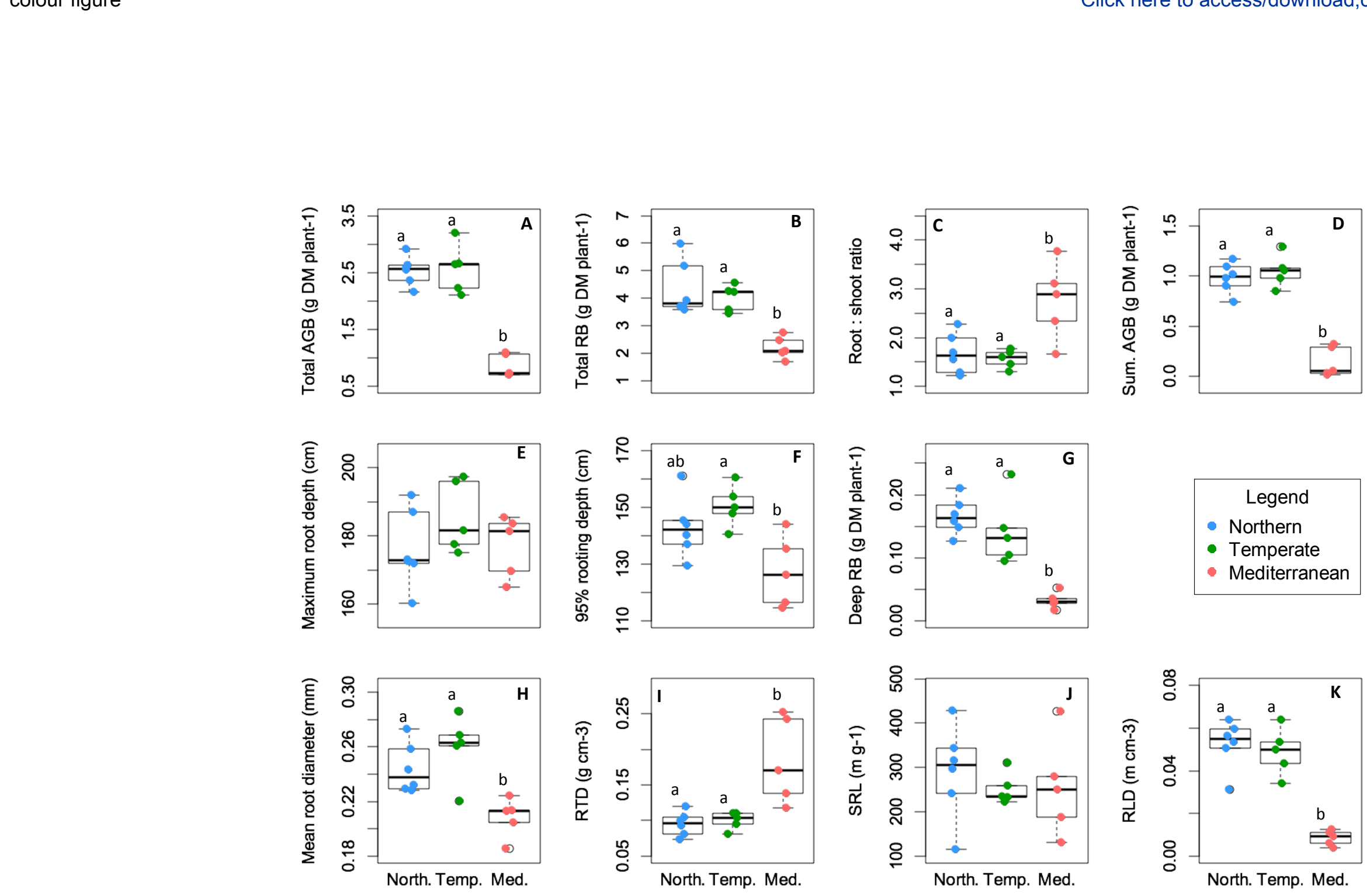

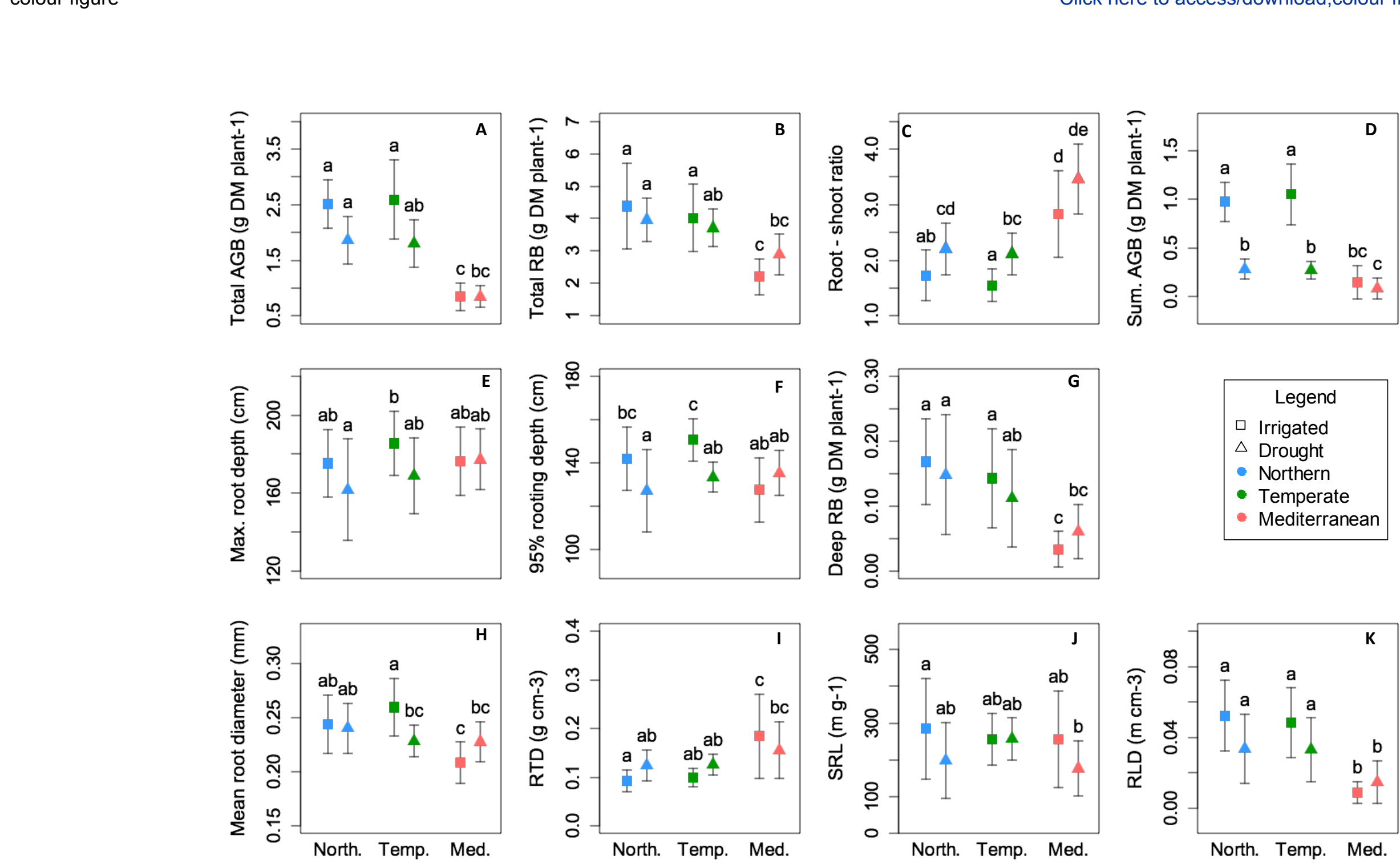

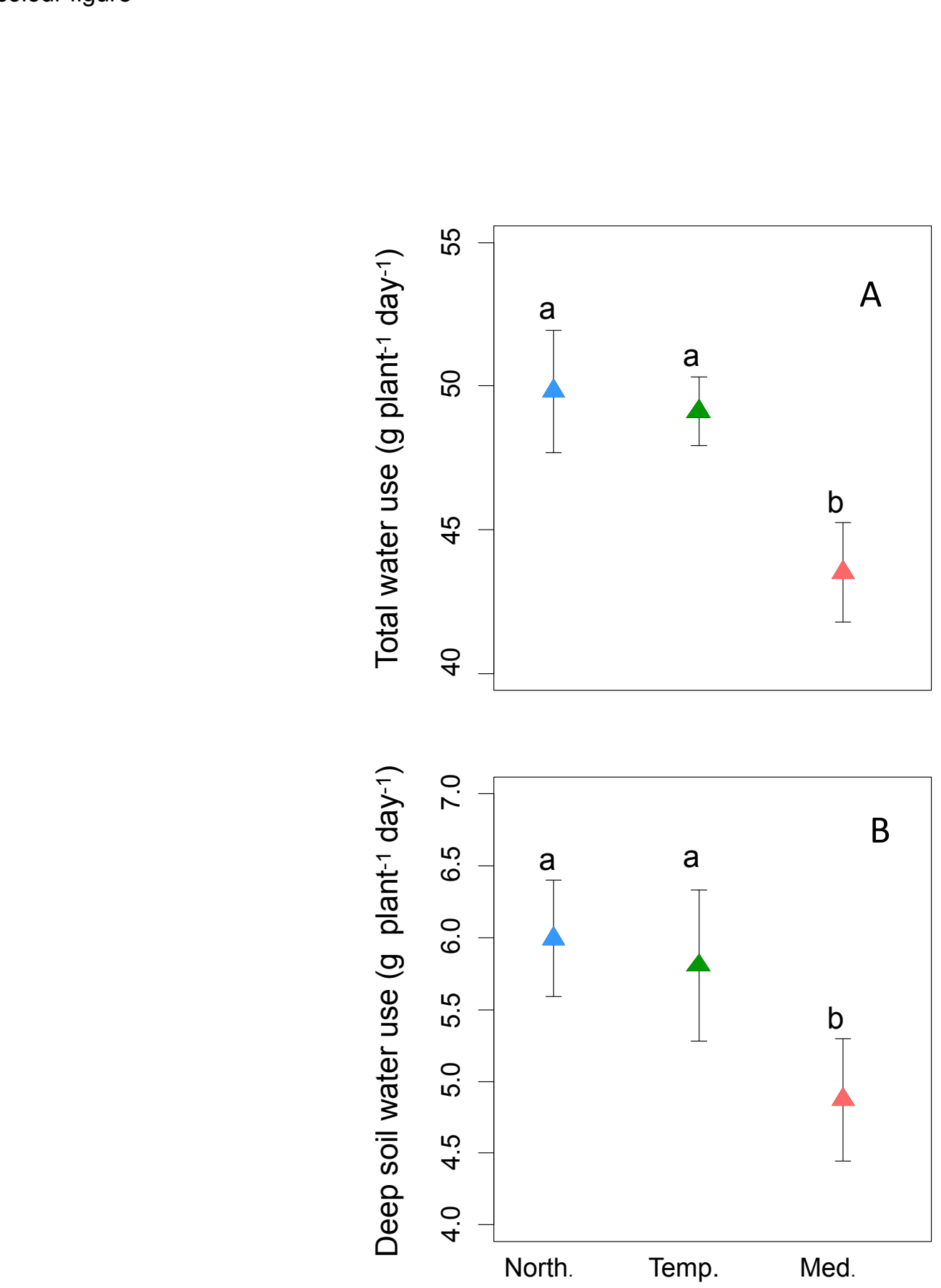

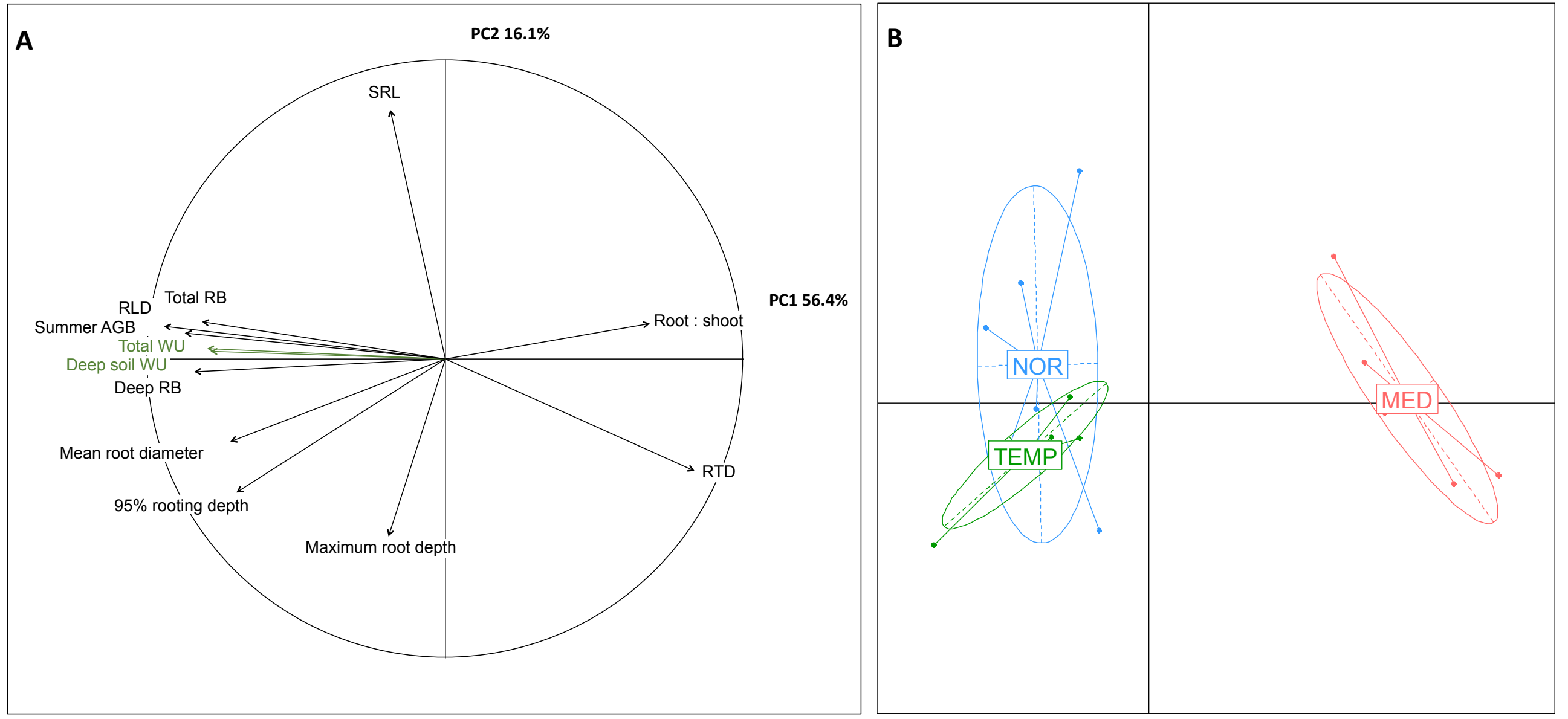


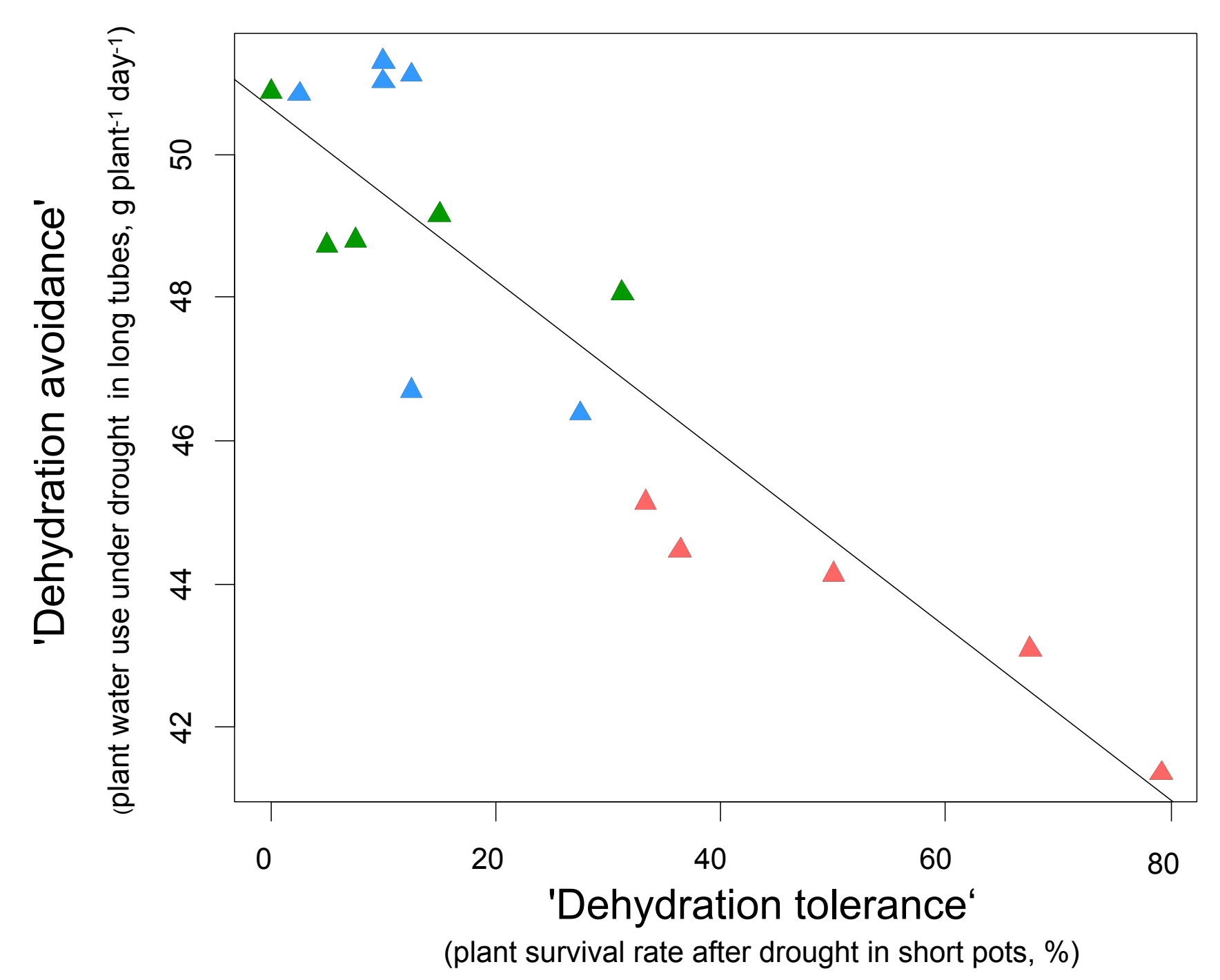

(plant survival rate after drought in short pots, \%) 


\begin{tabular}{|c|c|c|c|c|c|c|c|c|}
\hline Population & Country & Type & Origin & Latitude & Longitude & $\begin{array}{c}\text { Mean annual } \\
\text { temperature }\left({ }^{\circ} \mathrm{C}\right)\end{array}$ & $\begin{array}{c}\text { Mean annual } \\
\text { rainfall ( } \mathrm{mm} / \text { year) }\end{array}$ & $\begin{array}{l}\text { Rainfall of the driest } \\
\text { month ( } \mathrm{mm} / \text { month) }\end{array}$ \\
\hline Sweden & Sweden & Native & Northern & 60.5 & 24.22 & 4.8 & 613 & 93 \\
\hline Norway & Norway & Native & Northern & 60.25 & 9.68 & 1.9 & 768 & 118 \\
\hline Denmark & Denmark & Native & Northern & 56.46 & 8.66 & 7.8 & 809 & 134 \\
\hline St Michel & France & Native & Temperate & 48.63 & -1.51 & 11.5 & 731 & 149 \\
\hline Fourchette & France & Native & Temperate & 48.17 & -2.75 & 10.8 & 857 & 153 \\
\hline Carnac & France & Native & Temperate & 47.58 & -3.07 & 11.7 & 893 & 153 \\
\hline Sicily & Italy & Native & Mediterranean & 37.48 & 14.5 & 16.2 & 246 & 1 \\
\hline Morocco 14 & Morocco & Native & Mediterranean & 33.59 & -5.36 & 14.7 & 725 & 30 \\
\hline Morocco 1 & Morocco & Native & Mediterranean & 33.1 & -8.08 & 18 & 346 & 4 \\
\hline Morocco 9 & Morocco & Native & Mediterranean & 29.71 & -8.96 & 16.2 & 246 & 5 \\
\hline Hattfjelldal & Norway & Cultivar & Northern & - & - & - & - & - \\
\hline Tammisto & Finland & Cultivar & Northern & - & - & - & - & - \\
\hline Loke & Sweden & Cultivar & Northern & - & - & - & - & - \\
\hline Ludac & France & Cultivar & Temperate & - & - & - & - & - \\
\hline Porto & Portugal & Cultivar & Temperate & - & - & - & - & - \\
\hline Kasbah & Morocco & Cultivar & Mediterranean & - & - & - & - & - \\
\hline
\end{tabular}

Table S1. List of the 16 populations of Dactylis glomerata. Climatic data associated with their origins were collected from the WorldClim data set (http://www.worldclim.org; Hijmans et al., 2005). Seeds from Northern populations were provided by the Nordic Genetic Resource Center (NordGen). Temperate ecotypes and cultivars, and population 'Porto', were provided by the plant genetic resources information system of the National Institute for Agronomical Research (INRA, France, Lusignan). The Sicilian ecotype came from University of Catania, Italy. The Moroccan ecotypes came from INRA Rabat, Morocco. 
Table S2. Mean and range of the traits measured under irrigation or under drought on 16 populations of D. glomerata.

\begin{tabular}{|c|c|c|c|c|c|}
\hline \multirow[b]{2}{*}{ Variable } & \multicolumn{3}{|c|}{ Irrigated } & \multicolumn{2}{|l|}{ Drought } \\
\hline & Unit & Mean & Range & Mean & Range \\
\hline Total above ground biomass & g DM plant-1 & 2,02 & $0.69-3.20$ & 1,53 & $0.69-2.38$ \\
\hline Total root biomass & g DM plant-1 & 3,57 & $1.68-5.97$ & 3,55 & $2.52-4.56$ \\
\hline Root : shoot & - & 1,98 & $1.26-3.75$ & 2,54 & $1.69-3.77$ \\
\hline Summer above ground biomass & g DM plant-1 & 0,74 & $0.01-1.29$ & 0,21 & $0.02-0.39$ \\
\hline Maximum root depth & $\mathrm{cm}$ & 179 & $160-197$ & 169 & 139-188 \\
\hline $95 \%$ rooting depth & $\mathrm{cm}$ & 140 & $114-160$ & 131 & $113-148$ \\
\hline Deep root biomass & g DM plant-1 & 0,11 & $0.01-0.23$ & 0,1 & $0.03-0.24$ \\
\hline Mean root diameter & $\mathrm{mm}$ & 0,23 & $0.18-0.28$ & 0,23 & $0.21-0.26$ \\
\hline Root tissue density & $\mathrm{g} \mathrm{cm}-3$ & 0,12 & $0.07-0.25$ & 0,13 & $0.10-0.21$ \\
\hline Specific root length & m g-1 & 267 & $114-428$ & 212 & 81-289 \\
\hline Root length density & $\mathrm{m} \mathrm{cm}-3$ & 0,037 & $0.003-0.064$ & 0,027 & $0.007-0.057$ \\
\hline Total water use & g plant-1 day-1 & - & - & 47,3 & 41.3-51.3 \\
\hline Deep soil water use & g plant- 1 day- 1 & - & - & 5,6 & $4.5-6.3$ \\
\hline
\end{tabular}




\begin{tabular}{|c|c|c|c|c|c|c|c|c|c|}
\hline \multirow{2}{*}{$\begin{array}{l}\text { D. glomerata } \\
\text { populations }\end{array}$} & \multirow{2}{*}{$\begin{array}{l}\text { Summer } \\
\text { Treatment }\end{array}$} & \multicolumn{8}{|c|}{ Root biomass distribution (g DM plant ${ }^{-1}$ ) per soil layers in $2 \mathrm{~m}$ long tubes } \\
\hline & & $0-25 \mathrm{~cm}$ & $25-50 \mathrm{~cm}$ & $50-75 \mathrm{~cm}$ & $75-100 \mathrm{~cm}$ & $100-125 \mathrm{~cm}$ & $125-150 \mathrm{~cm}$ & $150-175 \mathrm{~cm}$ & $175-200 \mathrm{~cm}$ \\
\hline \multirow[t]{2}{*}{ Northern } & irrigation & $1.89 \pm 0.67$ & $1.01 \pm 0.30$ & $0.57 \pm 0.16$ & $0.36 \pm 0.16$ & $0.27 \pm 0.11$ & $0.20 \pm 0.09$ & $0.07 \pm 0.07$ & $0.012 \pm 0.024$ \\
\hline & drought & $2.10 \pm 0.38$ & $0.79 \pm 0.23$ & $0.46 \pm 0.15$ & $0.30 \pm 0.09$ & $0.20 \pm 0.10$ & $0.10 \pm 0.07$ & $0.02 \pm 0.02$ & $0.002 \pm 0.003$ \\
\hline \multirow[t]{2}{*}{ Temperate } & irrigation & $1.52 \pm 0.44$ & $0.86 \pm 0.26$ & $0.62 \pm 0.21$ & $0.37 \pm 0.11$ & $0.29 \pm 0.09$ & $0.21 \pm 0.09$ & $0.10 \pm 0.08$ & $0.024 \pm 0.038$ \\
\hline & drought & $1.82 \pm 0.32$ & $0.77 \pm 0.17$ & $0.49 \pm 0.11$ & $0.29 \pm 0.10$ & $0.21 \pm 0.07$ & $0.08 \pm 0.05$ & $0.02 \pm 0.02$ & $0.003 \pm 0.005$ \\
\hline \multirow[t]{2}{*}{ Mediterranean } & irrigation & $1.08 \pm 0.42$ & $0.67 \pm 0.26$ & $0.42 \pm 0.17$ & $0.26 \pm 0.12$ & $0.17 \pm 0.09$ & $0.10 \pm 0.08$ & $0.04 \pm 0.04$ & $0.007 \pm 0.012$ \\
\hline & drought & $1.42 \pm 0.36$ & $0.66 \pm 0.20$ & $0.43 \pm 0.17$ & $0.25 \pm 0.10$ & $0.19 \pm 0.08$ & $0.08 \pm 0.06$ & $0.02 \pm 0.03$ & $0.003 \pm 0.004$ \\
\hline
\end{tabular}

Table S3. Root biomass distribution in soil columns (0-200 cm length, $6 \mathrm{~cm}$ diameter): Mean ( \pm standard deviation) of root biomass $(\mathrm{g}$ DM plant $^{-1}$ ) for each $25 \mathrm{~cm}$ soil layer for Northern, Temperate and Mediterranean populations of D. glomerata under drought or irrigation. 
Table S4. Correlations between the total water use measured under drought and eleven traits measured under irrigation or under drought. The $R$ coefficient of Pearson correlations were represented with associated $\mathrm{P}$-value $(*, \mathrm{P}<0.05 ; * *, \mathrm{P}<0.01 ; * * *, \mathrm{P}<0.001 ;$ ns: not significant).

\begin{tabular}{|c|c|c|c|c|c|}
\hline & & \multicolumn{4}{|c|}{ Traits measured under } \\
\hline & & \multicolumn{2}{|l|}{ Irrigation } & \multicolumn{2}{|l|}{ Drought } \\
\hline & & $R$ Pearson & $P$ & $R$ Pearson & $P$ \\
\hline Total above ground biomass & g DM plant $^{-1}$ & 0,76 & $* * *$ & 0,76 & $* * *$ \\
\hline Total root biomass & g DM plant $^{-1}$ & 0,64 & $* *$ & 0,84 & $* * *$ \\
\hline Root : shoot & - & $-0,64$ & $* *$ & $-0,73$ & $* * *$ \\
\hline Summer above ground biomass & g DM plant $^{-1}$ & 0,77 & $* * *$ & 0,85 & $* * *$ \\
\hline Maximum root depth & $\mathrm{cm}$ & $-0,59$ & $* *$ & $-0,06$ & ns \\
\hline $95 \%$ rooting depth & $\mathrm{cm}$ & 0,21 & ns & 0,56 & $*$ \\
\hline Deep root biomass & g DM plant $^{-1}$ & 0,77 & $* * *$ & 0,85 & $* * *$ \\
\hline Mean root diameter & $\mathrm{mm}$ & 0,51 & $*$ & 0,80 & $* * *$ \\
\hline Root tissue density & $\mathrm{g} \mathrm{cm}^{-3}$ & $-0,53$ & $*$ & $-0,75$ & $* * *$ \\
\hline Specific root length & $\mathrm{m} \mathrm{g}^{-1}$ & $-0,47$ & ns & 0,07 & ns \\
\hline Root length density & $\mathrm{m} \mathrm{cm}^{-3}$ & 0,83 & $* * *$ & 0,89 & $* * *$ \\
\hline Deep soil water use & g plant $^{-1}$ day $^{-1}$ & & & 0,97 & $* * *$ \\
\hline
\end{tabular}




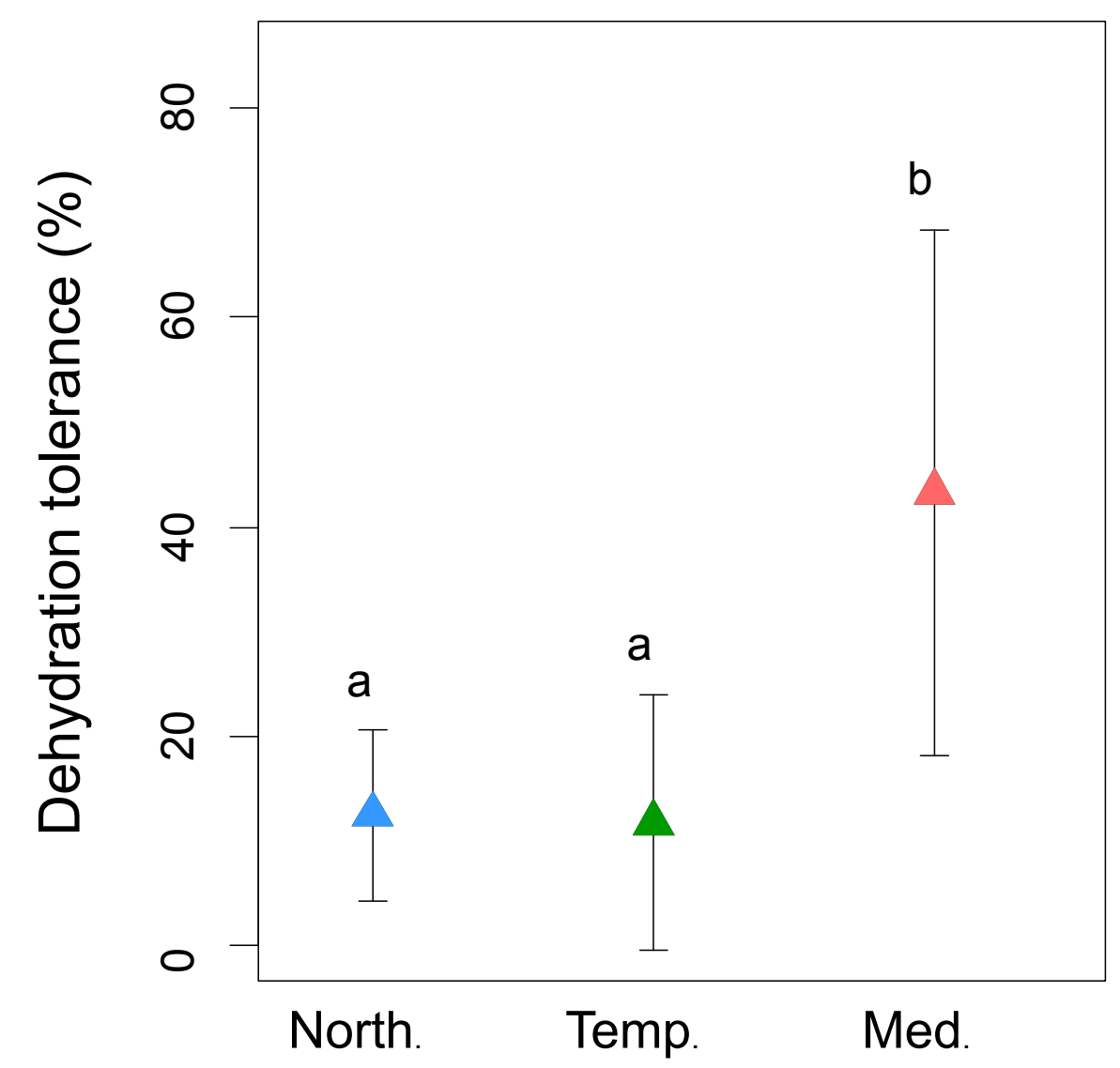

